\title{
Climate Change Projections and Their Consequences on Agro- Climate in Sugarcane Growing Areas of Sevanagala, Sri Lanka
}

L. M. J. R. Wijayawardhana ${ }^{1 *}$, K. D. N. Weerasinghe ${ }^{2}$ and C. M. Navaratne ${ }^{2}$

${ }^{1}$ Sugarcane Research Institute, Udawalawe, Sri Lanka.

${ }^{2}$ Faculty of Agriculture, University of Ruhuna, Mapalana, Kamburupitiya, Sri Lanka

\section{Correspondence:}

*Imjrw@yahoo.com

(iD) https://orcid.org/0000-0001-8876-3499

DOI: http://doi.org/10.4038/sljae.v3i1.59

\begin{abstract}
An analysis was conducted to estimate the agro-climatic changes, which would incur due to projected climate change scenarios on sugarcane cultivation in Sevanagala, Sri Lanka over the next 70 years. The general circulation model developed by the Beijing Meteorological Centre was used with Representative Concentration Pathways scenario 6.0 to simulate the climate variables of maximum and minimum temperatures, and rainfall for years 2030, 2050, and 2090. The goodness of fit test was conducted against simulated and observed data using 10-year dataset from 2010 to 2019. The future climate was compared using a baseline data set, which was generated by averaging 10 years of data from 2010 to 2019. The results indicated that by 2090, the average annual minimum and maximum temperatures would increase by $1.2{ }^{\circ} \mathrm{C}$ and $1.4{ }^{\circ} \mathrm{C}$, respectively. However, annual maximum and minimum temperatures may remain within the favourable range for sugarcane cultivation. The annual rainfall is expected to increase by $6.0 \%$ in 2090 relative to baseline values. The results demonstrated the stability of the effective rainfall. The evapotranspiration would increase by $3.7 \%$ by the year 2090 relative to baseline values. The soil moisture deficits for sugarcane planted in the Yala and Maha planting seasons are also expected to increase by $6.7 \%$ and $12.6 \%$, respectively in 2090 . As a result of increased evapotranspiration, additional irrigation might be needed to maintain the productivity of sugarcane cultivation indicating the climate-related risks for future rain-fed sugarcane cultivations in Sevanagala, Sri Lanka.
\end{abstract}

Keywords: Climate change scenarios, Climate projections, General circulation model, Potential evapotranspiration, Soil moisture deficit 


\section{Introduction}

The impact of global climate change on crop production is mainly due to changes in rainfall and temperature (Abeysingha et al. 2020). Climate forecasting models are used to study the combined effects of temperature and precipitation changes in future climates. Combined effect due to temperature and rainfall variation will create greater impact on rain-fed crops, while the temperature variation will have a high impact on irrigated crops. (Meng et al. 2017).

Climate change has increased the risk of frequent extreme weather events such as drought, high temperatures, low rainfall, and intense floods, which can be threatened on crop production (Meyer et al. 2011; Zhao and Li 2015). Most climate models have predicted the frequent occurrence of high intensity rainfall events in future (Tammets 2010; de Silva et al. 2007; Zhao and Li 2015) contributing to more runoff and less opportunity for infiltration (de Silva et al. 2007), affecting negatively on soil water balance of the root zone (Ali and Mubarak 2017). Therefore, current climate change would gradually reduce the productivity of most agricultural systems (Bradford et al. 2017). The impact of the climate change on diurnal variation of temperatures is also reported to be narrowing in elsewhere of the world (Kundu et al. 2017).

Sugarcane is a semi-perennial crop grown in Sri Lanka that has a great risk to expose the adverse effects of climate change (Kumarasinghe and Wijayawardhana 2011). In the tropics, sugarcane ripening perform well at daily maximum temperatures (day time temperature) around $29^{\circ} \mathrm{C}$ and daily minimum temperature (night time temperature) around $13{ }^{\circ} \mathrm{C}$ (Verma 2004). It is likely that in the areas where the daily minimum temperature increase resulting in decreasing sugar accumulation leading to a low sugar recovery at manufacturing stage (Hussain et al. 2018). The increase of maximum temperature due to climate change would proportionally increase the evapotranspiration rate (Kang et al. 2009), thereby rapidly reduce the available water content in the root zone soil. This scenario will have a high impact on rain-fed cultivation, where soil moisture refills only by the rainfall. Accordingly, increasing evapotranspiration while reducing the effectiveness of the rainfall would results increasing soil moisture deficits in most rain-fed areas of the world (Ali et al. 2017). However, according to Nisansala et al. (2019), the annual rainfall in the southern part 
of Sri Lanka is reported to increase during 1987-2017. Thus, it is necessary to determine the climate change impact on the agro-climate of rain-fed sugarcane producing area in Sri Lanka to develop possible adaptation strategies in advance to maintain economic competitiveness of the sugarcane cultivation. It helps to avoid further deterioration of productivity levels of sugarcane plantations and adapt policy decisions while finding of alternative pathways.

The present paper discusses the effect of climate changes on temperature, evapo transpiration, rainfall and soil moisture deficit levels in rain-fed sugarcane plantations in Sevanagala, Sri Lanka for the next 70 years period.

\section{Materials and Method}

The study was conducted in Sevanagala sugarcane project, Sri Lanka $\left(6^{\circ} 20^{\prime} \mathrm{N}\right.$ to $6^{\circ} 26^{\prime} \mathrm{N}$ and $80^{\circ} 50^{\prime} \mathrm{E}$ to $80^{\circ} 58^{\prime} \mathrm{E}$ ). MarkSim DSSAT weather file generator was used to simulate and predict daily maximum temperature $\left({ }^{\circ} \mathrm{C}\right)$, minimum temperature $\left({ }^{\circ} \mathrm{C}\right)$ and rainfall $(\mathrm{mm})$ data (Trotochaud et al. 2016; Welikhe et al. 2016). MarkSim software was capable to interpolate coarse grid data, usually between 1 and 2 degrees into smaller grids of 30 arc seconds using a bi-cubic convolution algorithm of downscaling (Jones et al. 2002). This downscaling procedure provided a reasonably fine data set for a given geographic location (Jones et al. 2002; Reynolds et al. 2018).

General Circulation Model (GCM) developed by Beijing Meteorological Centre of China (BCCCSM $1.1 \mathrm{~m}$ ) was used under Representative Concentration Pathways scenario 6.0 (RCP 6.0). RCP scenarios are named according to the radiative forcing level expected in the year 2100. At present, a set of four RCP scenarios were developed based on the radiative forcing levels of $8.5 \mathrm{Wm}^{-2}, 6 \mathrm{Wm}^{-2}, 4.5 \mathrm{Wm}^{-2}$, and 2.6 $\mathrm{Wm}^{-2}$. RCP 8.5 has been developed assuming the highest emissions projections, while RCP 6 available as a medium emission projection (Fujino et al. 2006; Hijioka et al. 2008). Many scientists have pointed out that the RCP 8.5 seems to be an over estimation (Fujino et al. 2006; Larry 2015) and not ideal to be used as a benchmark for future climate change studies (Ritchie and Dowlatabadi 2017). Therefore, this study used RCP 6.0 as a future projection scenario.

Goodness of fit test was conducted between simulated and observed data of monthly rainfall, maximum temperature, and minimum 
temperature for 10 years from 2010 to 2019 using root mean square error (RMSE), index of agreement and percent bias (PBIAS) tests as described by Legates and McCabe (1999).

RMSE $=\sqrt{\frac{\sum_{\mathrm{i}=1}^{\mathrm{n}}\left(\mathrm{O}_{\mathrm{i}}-\mathrm{P}_{\mathrm{i}}\right)^{2}}{\mathrm{n}}}$

$\mathrm{d}=1-\frac{\sum_{\mathrm{i}=1}^{\mathrm{n}}\left(\mathrm{O}_{\mathrm{i}}-\mathrm{P}_{\mathrm{i}}\right)^{2}}{\sum_{\mathrm{i}=1}^{\mathrm{n}}\left(\left|\mathrm{P}_{\mathrm{i}}-\overline{\mathrm{O}}\right|+\left|\mathrm{O}_{\mathrm{i}}-\overline{\mathrm{O}}\right|\right)^{2}}$

PBIAS $=\frac{\sum_{\mathrm{i}=1}^{\mathrm{n}}\left(\mathrm{P}_{\mathrm{i}}-\mathrm{O}_{\mathrm{i}}\right)}{\sum_{\mathrm{i}=1}^{\mathrm{n}}\left(\mathrm{O}_{\mathrm{i}}\right)} * 100$

where, RMSE $=$ Root mean square error; $d=$ Index of agreement, which is varied from 0 to 1 (Willmott 1981); PBIAS = Percent bias; $0=$ Observed values; $\mathrm{P}=$ simulated values; $\mathrm{n}=$ Number of observations; $d$ values closer to 1 indicates high goodness of fit between observed and simulated data; PBIAS closer to zero indicates better accuracy of the model.

\section{Effective rainfall}

There are many methods for estimating effective rainfall, including the soil water balance method and empirical relationships such as the USDA-SCS method. The best estimates of effective rainfall can be obtained by calculating soil water balance. Several studies have proved that the effective rainfall calculated by the USDA-SCS method under well drained soil closely follows the soil water balance method (Patwardhan et al. 1990). Thus, USDA-SCS method is one of the widely used methods to compute the monthly effective rainfall in many areas of the world (Patwar dhan et al. 1990). The USDA-SCS method is used in most of the crop simulation and irrigation scheduling models. As such, the USDA-SCS method was used in this analysis for computing the effective rainfall (Dastane 1978; Rahman et al. 2008; Bos et al. 2008; Ali and Mubarak 2017) as given in the equation 04 .

$\mathrm{Pe}=\mathrm{SF}\left(0.70917 \times \mathrm{Pt}^{0.82416}-0.11556\right) \times$

$\left(10^{0.2426 \mathrm{ETc}}\right)$

where, $\mathrm{Pe}=$ Monthly effective rainfall; $\mathrm{Pt}=$ Monthly mean rainfall; ETc = Average monthly crop evapotranspiration; $\mathrm{SF}=$ Soil water storage factor.

The soil water storage factor was calculated by using the equation 05 :

$$
\begin{aligned}
& \mathrm{SF}=\left(0.531747+0.295164 \mathrm{D}-0.057697 \mathrm{D}^{2}+\right. \\
& \left.0.003804 \mathrm{D}^{3}\right)
\end{aligned}
$$

where, $\mathrm{D}=$ Usable soil water storage as $50 \%$ of the available soil-water capacity in the 
sugarcane crop root zone of $90 \mathrm{~cm}$ depth which is equal to $60.03 \mathrm{~mm}$ for Rhodustalfs (Reddish Brown Earth soil/ RBE) dominant in Sevana gala (Wyseure et al. 1994; Wijayawardhana et al. 2014).

\section{Reference evapotranspiration}

Reference evapotranspiration (ETo) was computed using Hargreaves procedure as shown in the equation 06 (Mintz and Walker 1993; Yates and Strzepek 1994; Wang et al. 2015; Xiang et al. 2020). R software (4.0.3) was used for the estimation.

$\mathrm{ET}_{0}=0.0023 \times 0.408 \mathrm{Ra} \times \Delta \mathrm{T}^{0.5} \times(\mathrm{T}+$ 17.8)

where, $\mathrm{Ra}=$ Extra-terrestrial radiation which is a function of the latitude, $\Delta \mathrm{T}=$ Temperature difference (maximum- minimum), $\mathrm{T}=$ Mean air temperature $\left({ }^{\circ} \mathrm{C}\right)$.

\section{Soil moisture deficits}

Soil Moisture Deficit (SMD) depends upon the crop water requirement, the effective rainfall and planting season (Dastane 1978; Bos et al. 2008). Thus, soil moisture deficits for the sugarcane cultivations for the Yala and Maha planting season's planted crops were assessed. Rain-fed sugarcane in Sevanagala is cultivated basically under two planting seasons of the Yala and Maha (Wyseure et al. 1994; Wijayawar dahana et al. 2014). The Yala planting is done from March to April and Maha planting is done from September to October, respectively (Wijayawardahana et al. 2014).

Soil moisture deficits were computed using water balance equation (de Silva 2006) as given in the equation 07. Crop evapo transpiration in a given month can be computed with the equation $\mathrm{ET}_{\text {crop }}=\mathrm{K}_{\mathrm{c}} \mathrm{x} \mathrm{ET}_{0}$ (Allen et al. 1998; Xiang et al. 2020).

$\mathrm{SMD}=\left(\mathrm{K}_{\mathrm{c}} \times \mathrm{ET}_{0}\right)-\mathrm{P}_{\mathrm{e}}$

where, SMD = Soil moisture deficit in a given month (mm), $K_{c}=$ Crop factor. Value of the crop factor varies from $0.40,0.80,1.25$ and 0.75 depending on the growing stages of sugarcane crop namely germination, tillering, grand growth and maturity respectively (Win et al. 2014), $\mathrm{ET}_{0}=$ Reference evapotranspiration in a given month $(\mathrm{mm}), \mathrm{P}_{\mathrm{e}}=$ Effective rainfall in a given month (mm).

\section{Percent change}

A baseline dataset was produced by averaging a 10-year dataset from 2010 to 2019 in order to estimate relative changes in future climate. 
Percent change of annual maximum and minimum temperature, annual rainfall, annual effective rainfall and annual soil moisture deficits for the year 2030, 2050 and 2090 were compared using the equation 08.

Percent change $=\frac{x_{i}-x_{\text {base }}}{x_{\text {base }}} \times 100$

where, $\mathrm{x}_{\mathrm{i}}=$ Annual average maximum temperature, minimum temperature, annual crop water requirement or annual soil moisture deficits in $i^{\text {th }}$ year. xase $=$ baseline which was produced by averaging a 10 -year dataset.

\section{Results and Discussion}

\section{Goodness of fit test}

Statistics of the goodness of fit test conducted on maximum \& minimum temperatures and rainfall values simulated by the RCP 6.0 with observed data at Sevanagala are shown in scatter plot diagrams (Figure 1).
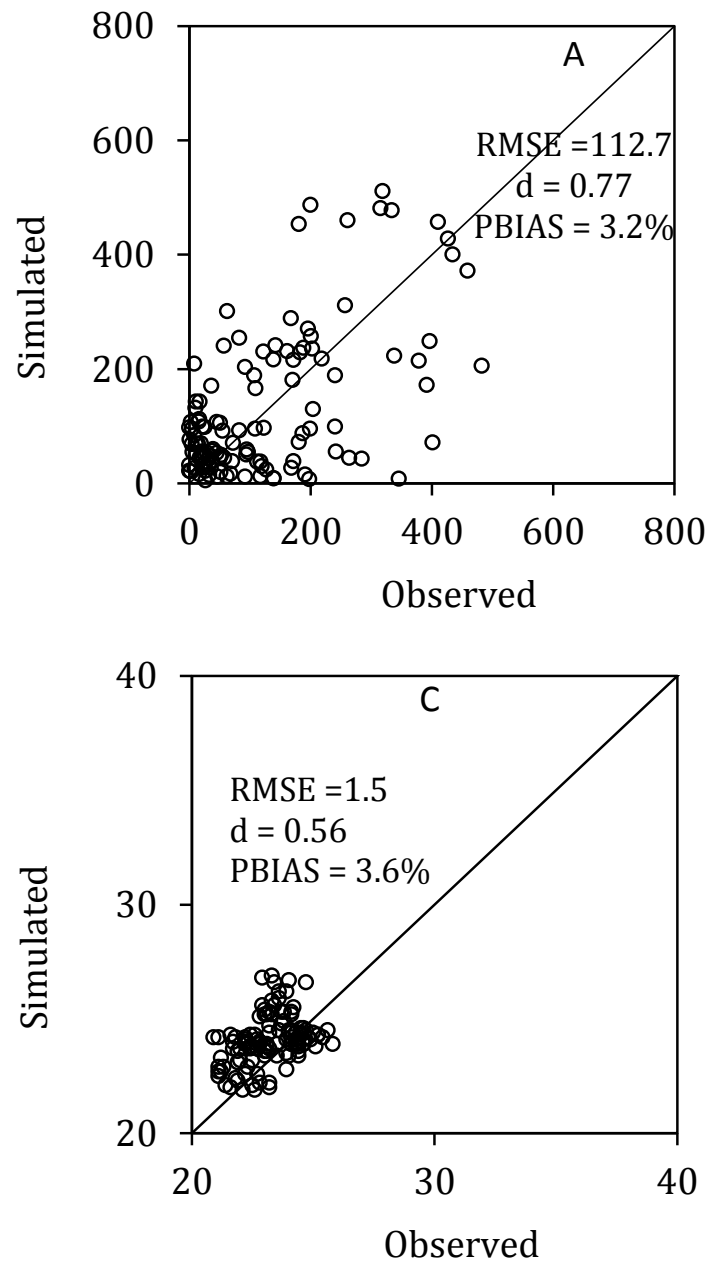

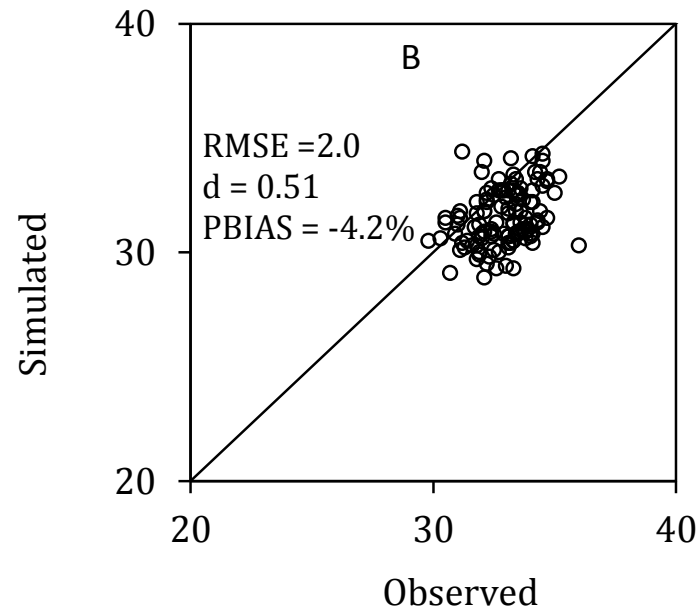

Figure 1. Root mean square error (RMSE), index of agreement (d), and percent bias (PBIAS) between the observed and RCP 6.0 scenario model output of rainfall (A), maximum (C), respectively. (B), and minimum temperature 
The calculated percent bias values for monthly rainfall, maximum and minimum temperatures were $3.2 \%,-4.2 \%$, and $3.6 \%$ respectively, which showed satisfactory model accuracy. Nevertheless, the index of agreement for rainfall $(d=0.77)$ shows ensured agreement between the simulated data and the actual data, while the maximum and minimum temperatures values showed average accuracy. Fundamentally, amount of rainfall varies greatly on temporal and spatial scale (Wickramagamage 2015). Since the analysis was done using observed data of one agro meteorological station, RMSE calculated against simulated and observed rainfall values showed a considerable variation. The calculated RMSE value for rainfall was 112.7. It reflects the level of uncertainty of RCP 6.0 scenario model output.

\section{Minimum and maximum temperature variation}

The variation of monthly mean maximum temperature, minimum temperature and their diurnal variations in 2030, 2050, 2090 and baseline values are depicted in Figure 2.

The annual average maximum temperature shows an increasing trend over time (Figure 2-
D), and it would rise by $1.4{ }^{\circ} \mathrm{C}$ by 2090 compared to the baseline value of $31.3{ }^{\circ} \mathrm{C}$.

Nevertheless, it would gradually reach $31.6^{\circ} \mathrm{C}$, $31.9{ }^{\circ} \mathrm{C}$, and $32.7^{\circ} \mathrm{C}$ by 2030,2050 , and 2090 , respectively. Similar trends (increasing of 1.6 ${ }^{\circ} \mathrm{C}$ ) have been observed previously by de Silva et al (2007).

The annual average minimum temperature in 2030, 2050, and 2090 are projected to be 24.4 ${ }^{\circ} \mathrm{C}, 24.6{ }^{\circ} \mathrm{C}$, and $25.3^{\circ} \mathrm{C}$ respectively (Figure 2). It is expected to increase the minimum temperature by $1.2{ }^{\circ} \mathrm{C}$ by the year 2090 compared to the baseline value of $24.1{ }^{\circ} \mathrm{C}$ (Figure 2-D), which is compatible with the observation made by de Silva et al. (2007). However, the present analysis reveals that elevated maximum and minimum temperature as shown in Figure 2 in Sevanagala would remain within a favorable range of $18{ }^{\circ} \mathrm{C}-35^{\circ} \mathrm{C}$ in terms of climatic requirement of sugarcane crop growth (James 2004).

It is also worth noting that the diurnal temperature variation increase by 0.2 degrees by 2090 relative to the baseline value (Figure 2D). Usually, increasing diurnal temperature difference enhances the cane quality (Verma 


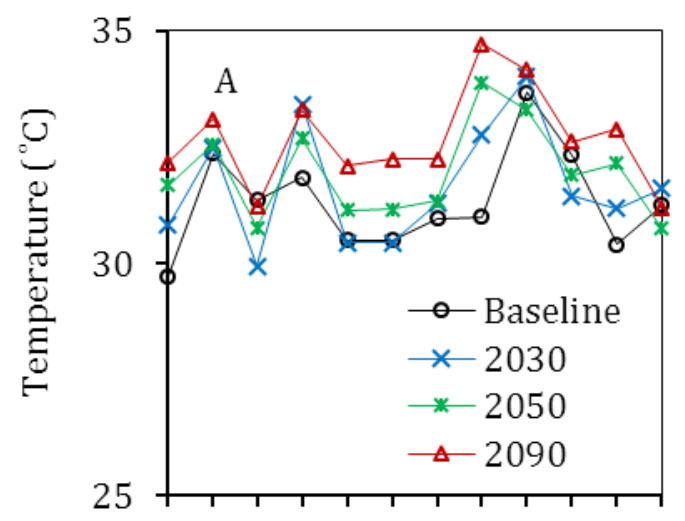

$\begin{array}{llllllllll}1 & 2 & 3 & 4 & 5 & 6 & 7 & 8 & 9 & 101112\end{array}$
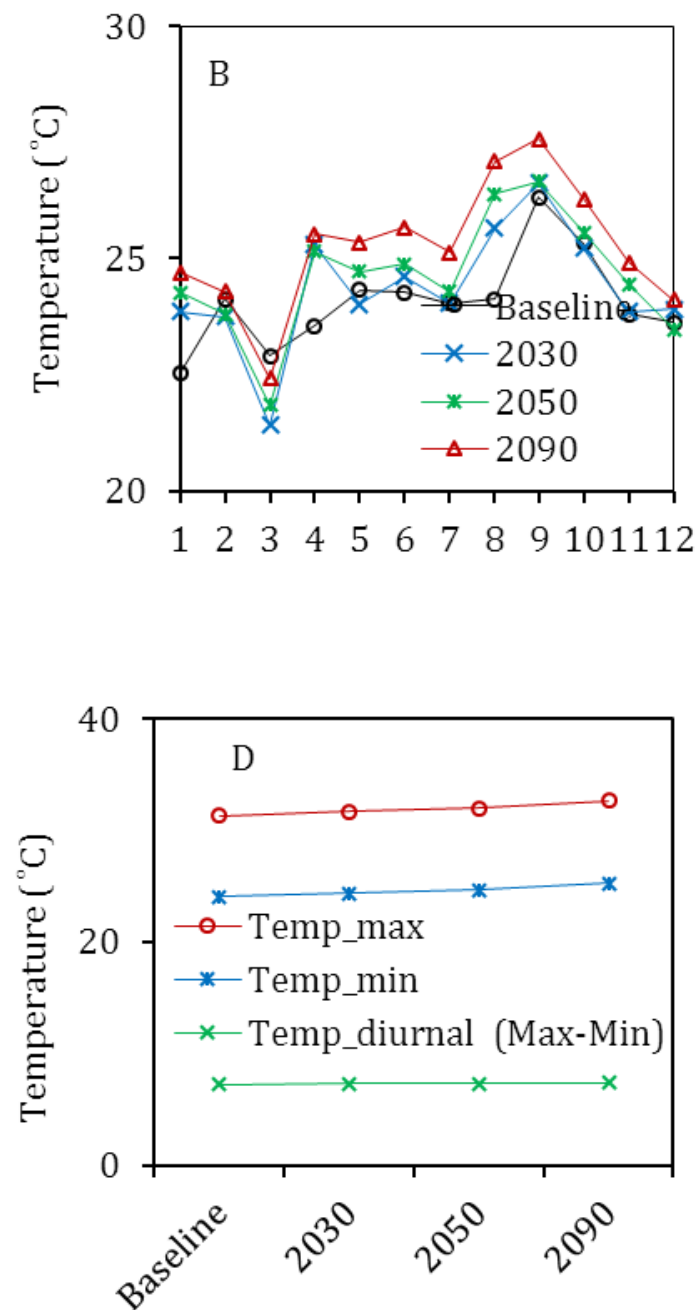

Figure 2. Variation of monthly mean maximum temperature (A), minimum temperature (B), diurnal temperature variations (C) and their annual variation (D). 1-12 in Figures 2A-C are months from January to December.

2004). However, the increase of maximum temperature during the day time would results in increased respiration, contributing to a decrease of number of physiological functions due to heat stress, thus direct benefit due to increasing diurnal temperature variation cannot be expected.

\section{Rainfall and effective rainfall}

Variation of monthly rainfall based on the RCP 6.0 scenario model output and calculated effective rainfall in 2030, 2050, and 2090 are plotted in Figure 3. 

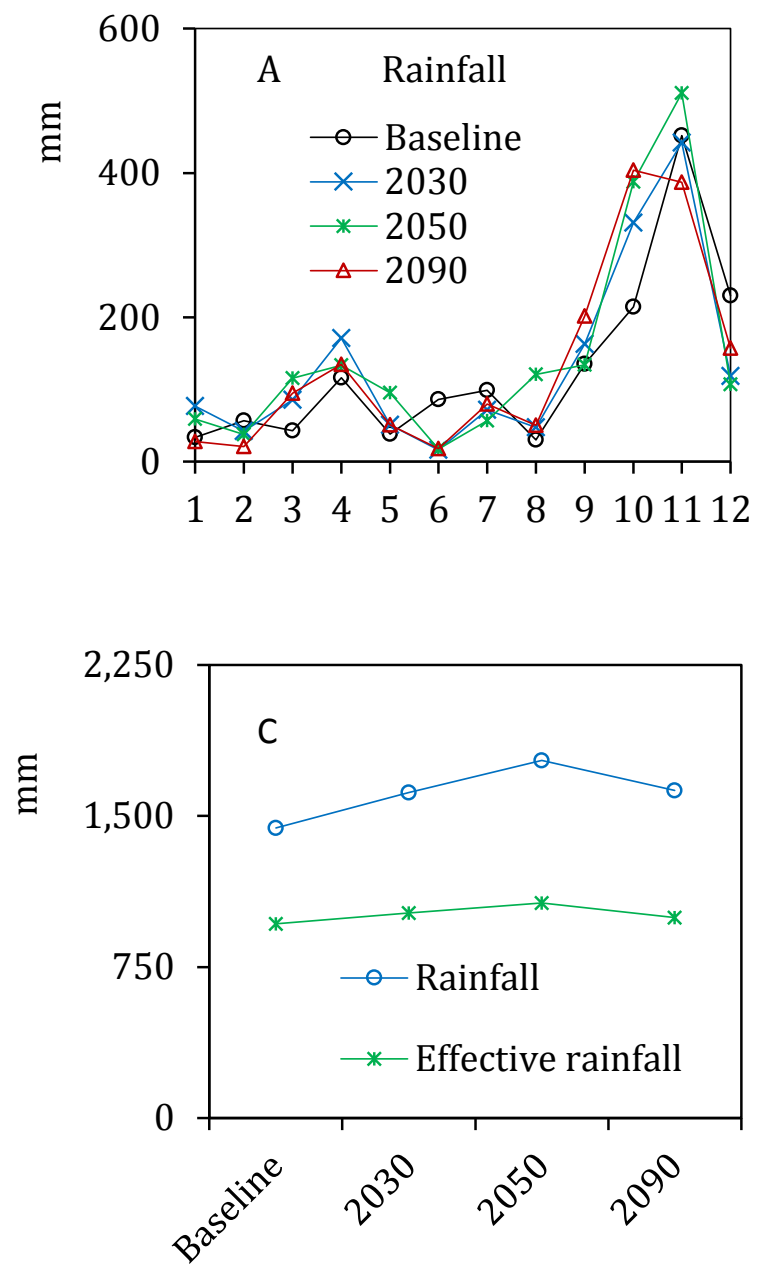

The projected annual rainfall in 2030, 2050, and 2090 would be $1,616 \mathrm{~mm}, 1,776 \mathrm{~mm}$ and $1,626 \mathrm{~mm}$ respectively. As such, it can be observed that the annual rainfall in 2090 would increase by $6.4 \%$ relative to the baseline value of $1,533 \mathrm{~mm}$. An increase in annual total rainfall in Sri Lanka was noticed by Nisansala et al. (2019) and de Silva et al. (2007). It is also worth noting the variation of annual effective rainfall which is estimated to be $1018 \mathrm{~mm}, 1068 \mathrm{~mm}$, and $995 \mathrm{~mm}$ in the years 2030, 2050, and 2090, respectively. Unlike the annual total rainfall,

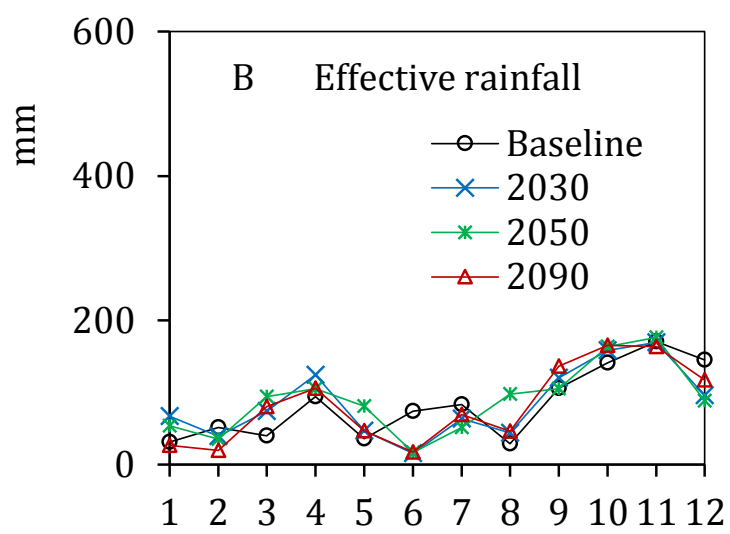

Figure 3. Variation of monthly rainfall (A), effective rainfall (B) and annual rainfall (C) at Sevanagala (1-12 in Figures $3 \mathrm{~A}-\mathrm{B}$ are months from January to December) the effective rainfall would change slightly during the study period (Figure 3-C). This shows that despite the increase in total annual rainfall, annual effective rainfall will not follow a similar pattern. This scenario may closely link to the elevation of high-intensity rainfall events in the future, as reported by Marambe et al. (2015). Since the intense rainfall would reduce the effectiveness of the rainfall contributing more to runoff and less to infiltration. As such, the effective rainfall may not follow the increasing pattern of the total rainfall. 


\section{Evapotranspiration}

From crop production point of view, evapotranspiration is the main parameter that influences the water requirement of a crop (Weerasinghe 1991; Yin et al. 2010). It gives a sense of the atmospheric water demand and characterizes the pressure created by the atmosphere on the vegetation. Variation of monthly total reference evapotranspiration $\left(\mathrm{ET}_{0}\right)$ in the years 2030, 2050, and 2090 at Sevanagala is demonstrated in Figure 4.

As per the present analysis, annual ETo levels are projected to be $1515 \mathrm{~mm}, 1525 \mathrm{~mm}$ and $1557 \mathrm{~mm}$ for 2030, 2050, and 2090 respectively. In 2090, the annual $\mathrm{ET}_{0}$ level

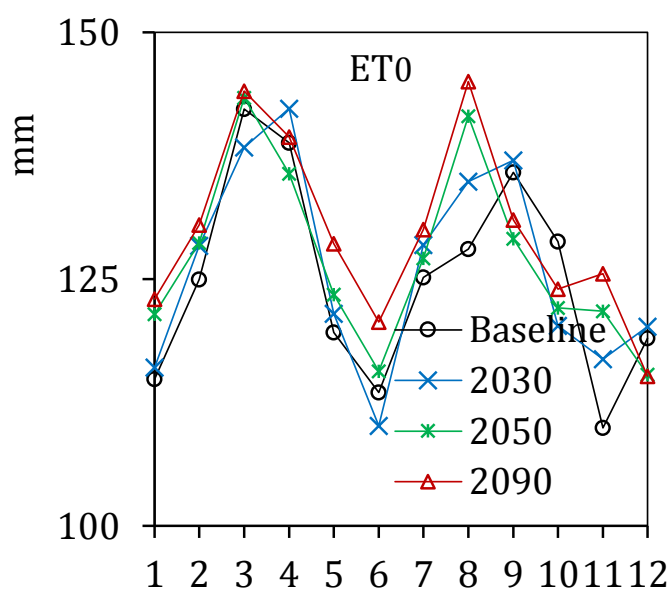

would increase by $3.7 \%$ compared to the baseline value of $1501 \mathrm{~mm}$.

\section{Soil moisture deficits}

Soil moisture deficit of the Yala (SMD_Yala) and Maha (SMD_Maha) planted sugarcane crop for the years 2030, 2050, 2090, and baseline values are shown in the Figure 5.

Soil moisture deficit for the Yala season planted sugarcane would be $467 \mathrm{~mm}, 426 \mathrm{~mm}$, and 497 $\mathrm{mm}$ in 2030, 2050, and 2090 respectively. Similarly, it would be $613 \mathrm{~mm}, 568 \mathrm{~mm}$, and $716 \mathrm{~mm}$ for the Maha season crop respectively. Baseline soil moisture deficit values were 466 $\mathrm{mm}$ and $636 \mathrm{~mm}$ for the Yala and Maha planting seasons respectively.

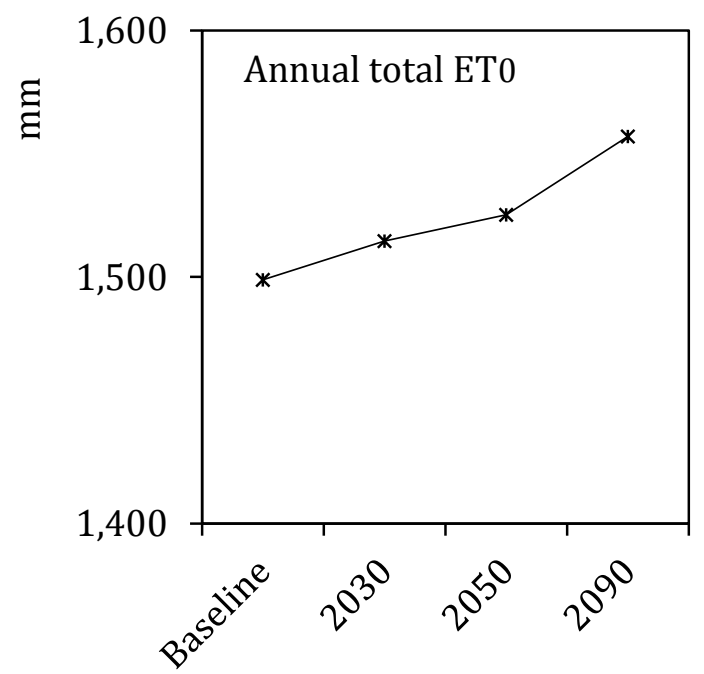

Figure 4. Variation of projected monthly and annual $\mathrm{ET}_{0}$ in the year 2030, 2050 and 2090 at Sevanagala (1-12 in Figure 4 are months from January to December) 

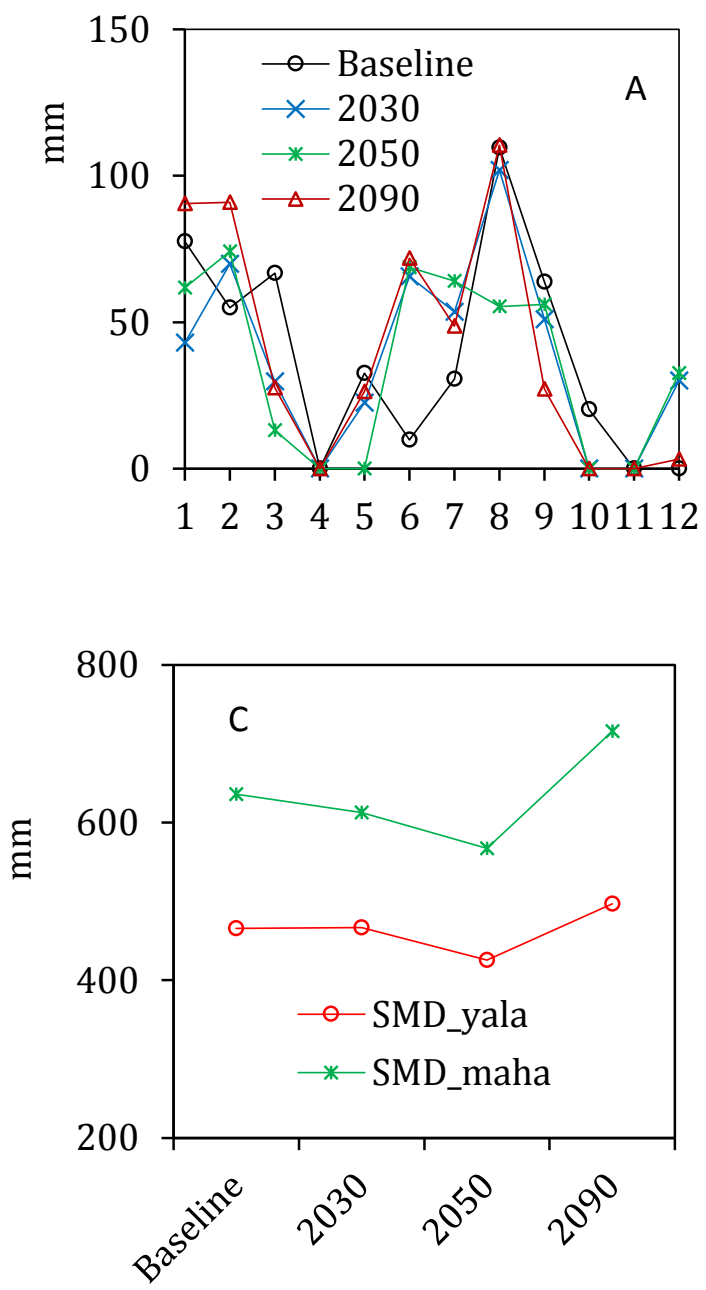

As shown in Figure 5, soil moisture deficits predicted for the coming 70-year period clearly showed that sugarcane planted in the Yala and Maha season would increase by $6.7 \%$ and $12.6 \%$ respectively (Figure $5-\mathrm{C}$ ). Nevertheless, predicted soil moisture deficits values clearly showed that sugarcane planted in the Maha season would suffer more water shortages than sugarcane grown in the Yala (Figure 5-C). The increase of soil moisture deficit would create a threat to rain-fed sugarcane cultivation in

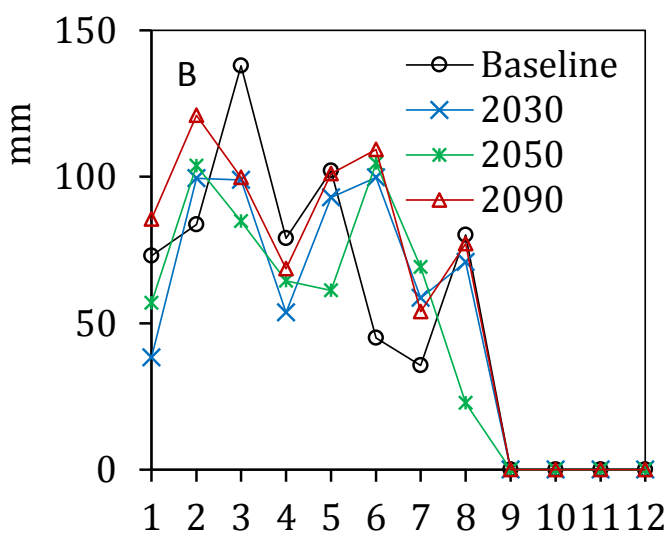

Figure 5. Variation of monthly soil moisture deficit of Yala (A) and Maha (B) planted sugarcane crop and their annual variations (C). (1 - 12 in Figures 5 A-B are months from January to December)

future. Therefore, prior adaption of runoff conservation and increase soil moisture recharging and storage measures with supplementary irrigation facilities can be practical strategies to overcome the issue. Similarly, the development of drought-resistant varieties is also very important to combat the elevated evapotranspiration and soil moisture shortage problems. As the long-term sustainability of the sugar industry, it is needed that funding by government or the sugar 
industry's internal capital for establishing new irrigation schemes. One of the possible strategies that can be completed with a limited budget is to construct small-scale runoff water harvesting structures in-situ in the sugarcane plantation (Wijayawardhana et al. 2011).

\section{Conclusions}

The projected agro-climatic parameters up to the year 2090 revealed that the rain-fed sugarcane cultivation in Sevanagala sugar project would be problematic due to elevated evapotranspiration and soil moisture deficit. However, the annual rainfall is expected to increase by $6.0 \%$ in 2090 relative to the baseline values. Furthermore, the analysis clearly noticed that the effective rainfall will remain at the current level over the study period.

The annual average maximum temperature will rise by $1.4^{\circ} \mathrm{C}$ and minimum temperature by 1.2 ${ }^{\circ} \mathrm{C}$ in 2090 compared to the baseline values. However, over the next 70 years, this rate of increase in temperature will not exceed the physiological desirable limit of $35{ }^{\circ} \mathrm{C}$ of the sugarcane crop.

\section{Acknowledgment}

Authors fully acknowledge the Sugarcane Research Institute of Sri Lanka for funding and facilitating this study.

Conflicts of interest: The authors have no conflicts of interest regarding this publication.

\section{References}

Abeysingha N S, Islam A and Singh M (2020) Assessment of climate change impact on flow regimes over the Gomti River basin under IPCC AR5 climate change scenarios. Journal of Water and Climate Change, 11(1), pp.303-326.

Ali M H and Mubarak S (2017) Effective rainfall calculation methods for field crops: an overview, analysis and new formulation. Asian Research Journal of Agriculture, pp.1-12.

Allen R G, Pereira L S, Raes D and Smith M (1998) Crop Evapo-transpiration, Guidelines for computing crop water requirements, $F A O$ Irrigation and Drainage Paper No. 56, Food and Agriculture Organization of the United Nations, Rome, 300.

Bos M G, Kselik R A, Allen R G and Molden D (2008) Water requirements for irrigation and 
the environment. Springer Science \& Business Media.

Bradford J B, Schlaepfer D R, Lauenroth W K, Yackulic C B, Duniway M, Hall S, Jia G, Jamiyansharav K, Munson S M, Wilson S D and Tietjen B (2017) Future soil moisture and temperature extremes imply expanding suitability for rain-fed agriculture in temperate dry-lands. Scientific reports, 7(1), pp.1-11.

Dastane N G (1978) Effective rainfall in irrigated agriculture. In FAO Irrigation and Drainage Engineering (FAO IRRIGA, Vol. 4, Issue 1). FA0, Rome, Italy.

de Silva C S (2006) Impacts of climate change on potential soil moisture deficit and its use as a climate indicator to forecast irrigation need in SriLanka, Symposium proceedings of the water professionals' day, Peradeniya, Sri Lanka

de Silva C S, Weatherhead E K, Knox J W and Rodriguez-Diaz J A (2007) Predicting the impacts of climate change - A case study of paddy irrigation water requirements in Sri Lanka. Agricultural water management, 93(12), pp.19-29.

Fujino J, Nair R, Kainuma M, Masui T, Matsuoka Y (2006) Multigas mitigation analysis on stabilization scenarios using aim global model. The Energy Journal Special issue 3:343-354

Hijioka Y, Matsuoka Y, Nishimoto H, Masui T, Kainuma M (2008) Global GHG emission scenarios under GHG concentration stabilization targets. J Glob Environ Eng 13:97108

Hussain S, Khaliq A, Mehmood U, Qadir T, Saqib M, Iqbal M A and Hussain S (2018) Sugarcane production under changing climate: effects of environmental vulnerabilities on sugarcane diseases, insects and weeds. Climate Change and Agriculture, IntechOpen.

James G (2004) Sugarcane (2nd ed.) Blackwell Publishing Company, 12-14

Jones P G, Thornton P K, Díaz W, Wilkens P W and Jones A L (2002) MarkSim: A computer tool that generates simulated weather data for crop modelling and risk assessment: version 1.

Kang Y, Khan S and Ma X (2009) Climate change impacts on crop yield, crop water productivity and food security- A review. Progress in natural Science, 19(12), pp.1665-1674.

Kumarasinghe N C and Wijayawardhana L M J R (2011) Effect of climatic conditions on sugarcane cultivation systems in Sri Lanka, in: 
International Conference on the Impact of Climate Change on Agriculture. Faculty of Agriculture, University of Ruhuna, Kamburupitiya Sri Lanka.

Kundu S, Khare D and Mondal A (2017) Future changes in rainfall, temperature and reference evapo-transpiration in the central India by least square support vector machine. Geoscience Frontiers, 8(3), pp.583-596.

Larry K (2015) A closer look at scenario RCP8.5, Climate-Etc.[online] https://judithcurry.com/ 2015/12/13/a-closer-look-at-scenario-rcp8.5

Legates D R and McCabe G J (1999) Evaluating the use of "goodness-of-fit" measures in hydrologic and hydroclimatic model validation. Water Resources Research, 35(1), 233-241

Marambe B, Punyawardena R, Silva P, Premalal S, Rathnabharathie V, Kekulandala B, Nidumolu U and Howden M (2015) Climate, climate risk, and food security in Sri Lanka: the need for strengthening adaptation strategies. Handbook of Climate Change Adaptation, pp.1759-1789.

Meng T, Carew R, Florkowski W J and Klepacka A M (2017) Analyzing Temperature and Precipitation Influences on Yield Distributions of Canola and Spring Wheat in Saskatchewan.
Journal of Applied Meteorology and Climatology $56,4,897-913$

Meyer J, Rein P, Turner P, Mathias K, McGregor C (2011) Good management practices manual for the cane sugar industry (Final). PGBI Sugar \& Bio-Energy (Pty) Ltd. South Africa.

Mintz Y and Walker G K (1993) Global fields of soil moisture and land surface evapotranspiration derived from observed precipitation and surface air temperature. Journal of Applied Meteorology, 32(8), pp.13051334.

Nisansala W D S, Abeysingha N S, Islam A and Bandara A M K R (2019) Recent rainfall trend over Sri Lanka (1987-2017). Int J Climatol. 2020; 40: 3417- 3435

Patwardhan A S, Nieber J L and Johns E L (1990) Effective rainfall estimation methods. Journal of Irrigation and Drainage Engineering, 116(2), 182-193

Rahman M M, Islam M O and Hasanuzzaman M (2008) Study of effective rainfall for irrigated agriculture in south-eastern part of Bangladesh. World Journal of Agricultural Sciences, 4(4), pp.453-457. 
Reynolds M, Kropff M, Crossa J, Koo J, Kruseman G, Molero M A, Rutkoski J, Schulthess U, Singh B, Sonder K, Tonnang H and Vadez V (2018) Role of modelling in international crop research: Overview and some case studies. Agronomy, $8(12)$.

Ritchie J and Dowlatabadi H (2017) Why do climate change scenarios return to coal?. Energy, 140, pp.1276-1291.

Tammets T (2010) Estimation of extreme wet and dry days through moving totals in precipitation time series and some possibilities for their consideration in agrometeorological studies. Agron Res, 8 (Special Issue II), pp.433438.

Trotochaud J, Flanagan D C and Engel B A (2016) A simple technique for obtaining future climate data inputs for natural resource models. Applied Engineering in Agriculture, 32(3), pp.371-381.

Verma R S (2004) Sugarcane Production Technology in India, International Book Distributing Company, Lucknow, India, pp.466

Wang W, Zhu Y, Xu R and Liu J (2015) Drought severity change in China during 1961-2012 indicated by SPI and SPEI. Natural Hazards, 75(3), pp.2437-2451.
Weerasinghe K D N (1991) Climatic Water Balance Approach for the Identification of Agro-climatological Regions in the Dry Zone of Sri Lanka. J. Natl. Sci. Counc. Sri Lanka 19, 151162.

Welikhe P, Essamuah Q J, Boote K, Asseng S and Afandi E G (2016) Impact of Climate Change on Corn Yields in Alabama. Professional Agricultural Workers Journal, 4, pp.1-14.

Wickramagamage P (2015) Spatial and temporal variation of rainfall trends of Sri Lanka. Theoretical and Applied Climatology 125(3-4).

Wijayawardhana L M J R, Abeyrathna K H D, Witharama W R G, Keerthipala A P (2011) Runoff water harvesters and agro-wells for supplementary irrigation of rain-fed sugarcane at Sevanagala in Sri Lanka: A preliminary investigation, in: $16^{\text {th }}$ Forestry and Environmental Symposium. University of Sri Jayawardhanapura.

Wijayawardhana L M J R, de Silva A L C, Witharama W R G (2014) Optimizing planting schedule of sugarcane for saving irrigation water in Sevanagala and Uda Walawe, Sri Lanka. Sugarcane Sri Lanka, pp. 1-7. 
Willmott C J (1981) On the validation of models. Physical Geography, 2, 184-194

Win S K, Zamora O B and Thein S (2014) Determination of the Water Requirement and Kc Values of Sugarcane at Different Crop Growth Stages by Lysimetric Method. Sugar Tech 16, 286-294

Wyseure G C L, Sanmuganathan K and Callaghan J R (1994) Use of simulation for combining rainfed and irrigated sugarcane production in the dry zone of Sri Lanka. Computers and electronics in agriculture, 11(4), pp.323-335.

Xiang K, Li Y, Horton R and Feng H (2020) Similarity and difference of potential evapotranspiration and reference crop evapotranspiration: a review. Agricultural Water Management, 232, p.106043.
Yates D and Strzepek K (1994) Potential evapotranspiration methods and their impact on the assessment of river basin runoff under climate change. Working Papers International Institute of Applied Systems Analysis, Laxenburg, Austria

Yin Y, Wu S and Dai E (2010) Determining factors in potential evapotranspiration changes over China in the period 1971-2008. Chinese Science Bulletin, 55(29), pp.3329-3337.

Zhao D and Li Y R (2015) Climate change and sugarcane production: Potential impact and mitigation strategies. International Journal of Agronomy. 